\title{
URGENSI PENELITIAN MANAJEMEN RANTAI PASOK: PEMETAAN ISU, OBJEK, DAN METODOLOGI
}

\author{
Sherlywati \\ Jurusan Manajemen, Fakultas Ekonomi, Universitas Kristen Maranatha, Bandung \\ Email: sherlywati.limijaya@gmail.com
}

Submitted: Nov 16, 2017; Reviewed: Nov 16, 2017; Accepted: Nov 22, 2017

\begin{abstract}
The purpose of this paper is to raise the issue of urgency of supply chain management research in terms of developmental issues, trends and challenges, as well as research objects and methologies in the any industry, business sector, and public sector. This study is an exploratory research with the aim of finding trends, developments, and challenges of current and potential supply chain management research. Data were collected from previous studies and written interviews from supply chain management experts where domiciled in several institutions in Bandung City. The findings of this study show expert opinion on the issues of supply chain management research in terms of developments, trends, and challenges, as well as the urgency of supply chain research. While, the results of the literature review from previous study, the research objects and methodologies of supply chain management research categorized into several categories that need to be concentrated for further research. Research suggestions are aimed specifically at academic, private and public sector practitioners to update and upgrade capacity, information, and knowledge about the development of supply chain management study in a sustainable manner. This paper also suggests to establish a community of supply chain management which consist of academicians, practitioners, and government in Bandung City to share informations and experiences about research and issues related to supply chain management, such as Supply Chain Indonesia (SCI) and American Production and Inventory Control Society (APICS).
\end{abstract}

Keywords: Supply Chain Management, Supply Chain Management Research, Issue of Supply Chain Management

\section{PENDAHULUAN}

Dalam era globalisasi, persaingan bisnis tidak lagi berupa kompetisi harga dan produk. Perusahaan yang memiliki pengelolaan rantai pasokan yang handal akan bertahan dan memenangkan persaingan di pasar. Kualitas mendengarkan keinginan konsumen akan berdampak pada kualitas pelayanan (Nicolae, dkk, 2012). Konsumen semakin kritis akan tuntutannya dalam hal penyediaan produk secara tepat tempat, tepat kuantitas dan kualitas, serta tepat waktu. Koordinasi yang baik antar mata rantai menjadi penentu keberhasilan pemenuhan permintaan konsumen. Koordinasi antar pihak sepanjang rantai pasok tidak hanya berbicara mengenai persediaan pasokan, tetapi melingkupi informasi kondisi pasar dan perencanaan perusahaan yang diintegrasikan dengan semua mata rantai yang terlibat secara langsung maupun tidak langsung. Koordinasi dan kerjasama antar mata rantai akan membuat keharmonisan dalam berbagi informasi mengenai penawaran dan permintaan konsumen. Proses koordinasi dan kerjasama dalam seluruh mata rantai dikelola dalam manajemen rantai pasokan (supply chain management).

Selain di sektor bisnis (privat), manajemen rantai pasokan menjadi perhatian khusus di sektor publik. Bulan Juni 2017, Kementrian Koordinator bidang Perekonomian meluncurkan paket kebijakan jilid XV yang fokus pada perbaikan sistem logistik nasional yang mencakup empat hal pokok. Pertama, kesempatan peningkatan peran dan skala usaha, kedua, kemudahan berusaha dan pengurangan beban biaya bagi usaha penyedia jasa logistik 
nasional, ketiga, penguatan kelembagaan dan kewenangan Indonesia National Single Window (INSW), dan keempat, penyederhadaan tata niaga untuk mendukung kelancaran arus barang (Fazli, 2017). Pemerintah juga mengatur sistem logistik nasional dalam Peraturan Presiden nomor 26 tahun 2012 dalam cetak biru tentang pengembangan sistem logistic nasional untuk dijadikan panduan dalam mengelola sistem logistik secara nasional, baik bagi kelembagaan negara maupun badan usaha di Indonesia. Peran sistem logistik nasional adalah meningkatkan daya saing serta kesejahteraan masyarakat Indonesia. Keberadaan cetak biru sistem logistik nasional ini adalah memberikan arahan dan pedoman bagi pemerintah dan dunia usaha dalam membangun sistem logistik yang mendukung pembangunan ekonomi nasional.

Konsep manajemen rantai pasok bukan merupakan konsep yang baru dalam bidang manajemen operasi. Konsep supply chain management (SCM) menekankan pada pola yang terintegrasi dalam proses aliran produksi mulai dari bahan mentah sampai produk tiba di tangan konsumen. Aktivitas yang terjadi sepanjang proses tersebut adalah suatu kesatuan yang perlu dipastikan kelancaran alirannya tanpa pembatas/penyekat sehingga mekanisme informasi berlangsung secara transparan tanpa reduksi di salah satu mata rantai. Penerapan SCM akan mengurangi biaya-biaya operasi yang terjadi di sepanjang mata rantai, memastikan kualitas produk tetap terjaga, yang pada akhirnya akan berkontribusi memberikan value kepada konsumen dalam hal ketersediaan produk dan kecepatan layanan. Dengan demikian pengelolaan rantai pasok akan memberikan keunggulan bersaing baik secara langsung maupun tidak langsung terutama pada nilai (value) produk.

Konsep manajemen rantai pasok bermula dari konsep logistik. Dengan perkembangan jaman, konsep logistik bergeser menjadi manajemen rantai pasokan. Fokus dari kegiatan logistik adalah mendistribusikan barang dan jasa pada tempat, jumlah, dan waktu yang tepat. Menurut Felicia (2003), kegiatan logistik tradisional (traditional logistic) merupakan kegiatan pemindahan atau pergerakan barang yang dimulai dari pengiriman bahan baku, komponen, energi, dan masukan lainnya menuju tempat produksi untuk diolah (physical supply channel/inbond logistic), kegiatan pemindahan selama proses pengolahan (intern logistic), kegiatan pengiriman produk kepada konsumen 148 (physical distribution channel/outbond logistic). Sebelum abad 20, misi utama dari kegiatan logistik adalah menyediakan produk bagi konsumen, dan mengelola pendistribusian agar produk tersebut dapat tiba di tangan konsumen sesuai dengan keinginan dan kebutuhan, jumlah dan waktu, serta kualitas yang sesuai standar perusahaan. Inti dari kegiatan logistik tradisional adalah pergerakan fisik mulai dari pemasok bahan mentah sampai ke konsumen.

Ruang lingkup konsep manajemen rantai pasok jauh lebih luas dibandingkan konsep logistik. Menurut Lambert, Cooper, dan Pagh (1998), manajemen rantai pasok adalah integrasi proses bisnis dari pengguna akhir melalui pemasok awal yang menyediakan produk, jasa, dan informasi dalam rangka memberikan nilai tambah bagi konsumen dan pemangku kepentingan lainnya. Garside (2015) mendefinisikan supply chain sebagai kumpulan para pelaku usaha yang terlibat dalam serangkaian proses bisnis dalam suatu rantai pasokan. Mentzer (2001) mengungkapkan tujuan dari SCM adalah mensinkronkan kebutuhan konsumen dengan arus bahan baku dari pemasok untuk menghasilkan keseimbangan antara pelayanan konsumen yang baik, pengelolaan inventori yang rendah, dan biaya unit produk yang rendah.

Permasalahan yang seringkali muncul terkait rantai pasok sehingga daya saing produk Indonesia rendah adalah biaya logistik yang tinggi dan waktu pengiriman. Hal ini dipengaruhi oleh fasilitas logistik yang masih konvensional, seperti pelabuhan dan konektivitas yang berkaitan antara pusat produksi dan konsumsi (Primiana, Azis, Juanim, Yunani, \& Herwany, 2016). Salah satu mereduksi biaya logistik adalah dengan optimalisasi distribusi material dari pemasok, aliran material dalam proses produksi sampai dengan distribusi produk ke tangan konsumen (Wiyarto, 2012). Sidharan dan Simatupang (2013) memberikan wawasan baru tentang peran kekuasaan dan kepercayaan yang memfasilitasi anggota rantai untuk mengumpulkan kemampuan mereka dalam menciptakan dan menghargai nilai bagi pelanggan dan diri mereka. Kekuatan dan kepercayaan menjadi salah satu faktor penting dalam kolaborasi manajemen rantai pasok (Sidharan \& Simatupang, 2013). Sharma, Garg, dan Agarwal (2012) mengupas konsep kualitas manajemen rantai pasokan, dan memaparkan bahwa kualitas rantai pasokan dapat memberikan solusi pada tingkat pengelolaan rantai pasokan. 
Dengan konsep kualitas manajemen pada rantai pasokan, perusahaan dapat mengatasi masalah rantai pasokan seperti recall produk dan keterlambatan pengiriman terlepas dari jenis industri.

Seiring dengan perkembangan konsep logistik menjadi manajemen rantai pasokan, SCM memiliki peran strategis dalam meningkatkan kinerja sektor privat, organisasi non-profit, maupun kelembagaan pemerintahan negara di Indonesia. Manajemen rantai pasok hadir sebagai perkembangan paradigma persaingan bisnis dari persaingan harga menuju persaingan rantai pasokan. Kondisi perkembangan ini menuntut sinergi antara akademisi, pelaku usaha, dan pengelola kelembagaan menyiapkan strategi pengelolaan mata rantai yang disebut manajemen rantai pasokan. Penelitian ini memperlihatkan sejauh mana kemendesakan penelitian-penelitian bertopik manajemen rantai pasokan diperlukan dan sedang dilibatkan dalam rangka membangun strategi yang terintegrasi pada sistem bisnis rantai pasok. Harapan dari penelitian ini adalah dapat memberikan kontribusi berupa informasi situasi dan kondisi aktual penelitian-penelitian manajemen rantai pasokan, yang sekiranya dapat dijadikan masukan bagi perkembangan pelaku usaha maupun kemajuan pelayanan sektor publik dalam rangka penyusunan strategis dan pelaksanaan teknis sistem manajemen rantai pasokan secara internal maupun koordinasi dan kerjasama dengan pihak eksternal.

\section{TINJAUAN KEPUSTAKAAN Supply Chain}

Supply chain (rantai pengadaan) menurut Indrajit (2002) dalam buku "Konsep Manajemen Supply Chain" adalah suatu sistem tempat organisasi menyalurkan barang produksi dan jasanya kepada para pelanggan. Rantai pengadaan merupakan jejaring yang terdiri dari berbagai organisasi yang saling berhubungan secara mutualisme dalam mengadakan dan menyalurkan produk. Pujawan (2005) dalam bukunya Supply Chain Management mendefinisikan supply chain sebagai jaringan perusahaan-perusahaan yang secara bersama-sama bekerja untuk menciptakan dan menghantarkan suatu produk ke tangan pemakai akhir. Yang dimaksud dengan jaringan perusahaan adalah pemasok, pabrik, distributor, ritel, serta perusahaan pendukung seperti jasa pengiriman/pengangkutan. Menurut Simatupang (2013) dalam buku "Logistik and Supply Chain in Indonesia: Emerging Practices", mendefinisikan rantai pasokan sebagai jaringan logistik yang saling terkait dan dikelola oleh beberapa perusahaan dari sumber bahan baku ke lokasi penggunaan.

Jadi jelas bahwa supply chain adalah jaringan fisik, terdiri dari perusahaan-perusahaan yang bekerjasama dalam memasok bahan baku, mengolahnya menjadi barang jadi, dan mengantarkannya kepada pemakai akhir. Pengelolaan jaringan rantai pasokan memberikan indikasi bagi organisasi untuk melakukan pengkoordinasian kebutuhan dan keinginan konsumen, pengendalian proses produksi, pendistribusian produk yang sesuai dengan permintaan konsumen, serta pengembangan sistem informasi yang terintegrasi. Koordinasi dan kolaborasi antar stakeholder pada rantai pasokan dapat meminimasi biaya persediaan dan biaya pendistribusian dalam rangka meningkatkan pelayanan di sepanjang rantai pasokan.

\section{Supply Chain Management}

Pada tahun 1980an, Oliver dan Weber memaparkan istilah SCM untuk pertama kalinya sebagai pendekatan manajemen persediaan dengan penekanan pada pengadaan bahan baku. Dalam Busines Review 2008, Dr. Douglas Lambert mengatakan bahwa SCM adalah model bisnis terpadu yang mengambil pandangan berbasis proses tentang bagaimana semua fungsi bisnis perlu bekerja sama dan berhubungan dengan pemasok serta pelanggannya (Kane, 2008). Sistem bisnis yang terpadu ini dibangun oleh arus informasi, arus produk, dan proses bisnis rantai pasokan yang melibatkan fungsional-fungsional perusahaan. Menurut Lina Anatan dan Lena Ellitan (2008) dalam buku "Supply Chain Management: Teori dan Aplikasi", manajemen rantai pasokan merupakan strategi alternatif yang memberikan solusi dalam menghadapi ketidakpastian lingkungan untuk mencapai keunggulan kompetitif melalui pengurangan biaya operasi dan perbaikan pelayanan konsumen serta kepuasan konsumen.

Jadi supply chain management (SCM) merupakan metode, alat, atau pendekatan yang terintegrasi dalam mengelola rantai pasokan dengan semangat kolaborasi dan koordinasi. Pengelolaan SCM akan melibatkan internal dan eksternal perusahaan yang terlibat dalam rangka memuaskan konsumen akhir yang sama. Seluruh stakeholder perlu berkoordinasi dan berkolaborasi dapat menciptakan produk yang tepat layanan, tepat kualitas, tepat kuantitas, 
tepat waktu, dan tepat tempat. Semangat kolaborasi dan koordinasi ini terbentuk dengan adanya kesadaran bahwa ketangguhan rantai pasokan akan bergantung pada kekuatan masingmasing elemen yang bersinergi dalam menjalankan sistem manajemen rantai pasokan. Dengan demikian, proses bisnis menjadi proses bisnis rantai pasokan yang saling terkait dalam batas-batas intra dan antar perusahaan.

\section{Ruang Lingkup Supply Chain Management}

Cakupan kegiatan SCM adalah seluruh aktivitas yang terjadi terkait aliran materi, aliran uang, dan aliran informasi di sepanjang mata rantai perusahaan. Menurut Prof. Ina Primiana dari Universitas Padjajaran pada tulisan "Prioritas Industri Strategis: Pemetaan Supply Chain Management sudah Mendesak" di Pikiran Rakyat, 17 Februari 2017, mengatakan bahwa manajemen rantai pasok pada seluruh tahapan industry mulai dari perijinan, produksi, distribusi, hingga pada pemasaran di tiga industri strategis, tekstil, barang kulit, dan alas kaki, semen, dan barang galian logam serta logam dasar besi dan baja (Primiana, 2017). Cakupan kegiatan SCM menurut Furqon (2014) adalah segala aktivitas yang terintegrasi termasuk didalamnya aliran informasi yang berkaitan dengan tiga aspek, yaitu 1) sumber, 2) proses produksi, 3) proses penghantaran produk. Selain itu ada tiga komponen dalam rantai pasok, yaitu 1) rantai pasokan hulu (upstream supply chain), meliputi berbagai aktivitas dengan pemasok; 2) rantai pasokan internal (internal supply chain), meliputi seluruh proses pemasukan barang ke gudang yang digunakan sampai proses produksi dan pengendalian persediaan; 3) rantai pasokan hilir (downstream supply chain), meliputi semua aktivitas yang melibatkan pengiriman produk kepada pelanggan, yang fokus utama kegiatannya adalah distribusi, transportasi, dan pelayanan. Sementara menurut Russell dan Taylor (2006), rantai pasokan mencakup seluruh aktivitas terkait arus dan transformasi barang dan jasa dari tahap bahan baku sampai pengguna akhir dimana rantai pasokan mengintegrasikan kelompok proses operasi kepada sumber bahan baku, proses produksi, serta mengirimkan produk.

\section{Tantangan Supply Chain Management}

Dengan banyaknya pihak yang terlibat dalam pengelolaan rantai pasokan, perusahaan mempunyai tantangan yang akan ditemui dalam proses bisnis rantai pasokannya. Beberapa 150 tantangan yang harus dihadapi perusahaan dalam mengelola rantai pasokannya, menurut Pujawan (2005), adalah pertama, kompleksitas rantai pasokan, dan kedua, faktor ketidakpastian. Kompleksitas rantai pasokan terjadi karena banyaknya pihak yang terlibat, dan setiap pihak memiliki kepentingan tujuan masing-masing yang seringkali saling bertentangan (conflicting of objective). Konflik antar bagian yang mungkin terjadi ini merupakan tantangan besar yang perlu dihadapi dalam mengelola rantai pasokan. Sementara faktor ketidakpastian juga menjadi tantangan perusahaan dalam menjalankan proses bisnis rantai pasokan. Tiga sumber ketidakpastian yang utama pada rantai pasokan adalah ketidakpastian permintaan, ketidakpastian pemasok, dan ketidakpastian dari pihak internal. Perusahaan perlu mengantisipasi ketiga ketidakpastian tersebut. Tindakan antisipasi dilakukan dalam rangka mengamankan kelancaran aliran barang, aliran uang, dan aliran informasi pada rantai pasokan. Hal yang dapat dilakukan perusahaan dalam rangka mengantisipasi ketidakpastian tersebut adalah misalnya dengan mengadakan safety stock, safety time, kapasitas produksi yang longgar, dan pemeliharaan yang berkelanjutan pada sistem dan mesin yang digunakan internal perusahaan.

Dari sudut pandang sistem logistik nasional, Indonesia masih tertinggal dibanding negara lain di Asia Tenggara. Pada tahun 2016, Bank Dunia menempatkan kinerja logistik Indonesia di posisi 63, menurun dari posisi 53 pada tahun 2012. Situasi ini yang mendorong pemerintah mengeluarkan paket kebijakan XV fokus pada perbaikan sistem logistik Indonesia (Bank T. W., 2015). Tantangan-tangangan utama dalam Peraturan Pemerintah nomor 26 tahun 2012 tentang cetak biru pengembangan sistem logistik nasional Indonesia ditujukan pada enam kenali utama Sislognas, yaitu (1) komoditas prime mover, (2) pengguna dan penyedia jasa logistik, (3) teknologi informasi dan komunikasi, (4) manajemen sumber daya manusia, infrastruktur transportasi, (6) peraturan, aturan, dan perundang-undangan ${ }^{1}$.

Centre for Supply Chain Information System Institut Harapan Bangsa mengatakan bahwa teknologi informasi dan komunikasi merupakan salah satu pendorong utama bagi sistem logistik nasional. Tantangan SCM adalah

\footnotetext{
${ }^{1}$ Peraturan Pemerintah no. 26 tahun 2012 tentang Cetak Biru Pengembangan Sistem Logistik Nasional Indonesia (Sislognas)
} 
memadukan proses logistik dengan teknologi informasi dan komunikasi. Pada umumnya sudah banyak perusahaan menggunakan sistem informasi dalam operasinya, namun ruang lingkup sistem informasi masih sebatas proses akuntansi. Perusahaan yang mengintegrasikan beberapa proses logistik dengan menggunakan perangkat lunak Enterprise Resource Planning (ERP) masih rendah jumlahnya dan hanya perusahaan besar yang dapat menjalankannya. Unit usaha kecil dan menengah (UKM) khususnya di Jawa Barat pada dasarnya masih menggunakan sistem manual untuk mengelola proses logistiknya (ITHB, 2015).

\section{METODE PENELITIAN}

\section{Desain dan Pendekatan Penelitian}

Desain penelitian ini adalah penelitian eksplorasi yang bertujuan untuk menemukan dan memotret tren, perkembangan, dan tantangan manajemen rantai pasok yang sedang dan akan terjadi. Penelitian dijalankan dengan cara mengumpulkan, menggali, dan mengkategorisasikan penelitian-penelitian terdahulu dan yang sedang berjalan serta mendapatka pemikiran dari para ahli SCM di beberapa institusi di kota Bandung. Studi yang bersifat eksploratif mempunyai tujuan utamanya adalah suatu penemuan (discovery) (Kuncoro, 2011), dan dalam penelitian ini adalah penemuan tren, perkembangan, serta tantangan penelitian bidang manajemen rantai pasok.

Pendekatan penelitian bersifat kualitatif dengan mengarahkan informasi dari narasumber dosen-dosen yang mendalami kajian manajemen rantai pasok. Target responden pada penelitian ini adalah ahli SCM, yaitu dosen di beberapa institusi perguruan tinggi kota Bandung yang berkecimpung pada bidang kajian manajemen operasi, khususnya manajemen rantai pasokan. Sumber data penelitian menggunakan data primer dan sekunder. Data primer berupa hasil wawancara langsung dengan responden, berupa informasi masukan, arahan, serta pengalaman dan pemahaman para dosen tentang keberadaan penelitian SCM. Data sekunder didapatkan melalui kajian literatur penelitian terdahulu dan data-data yang tersaji dari berbagai sumber terkait penelitian.

\section{Teknik Pengumpulan Data dan Instrumen Penelitian}

Teknik pengumpulan data dilakukan dengan cara kajian literatur dan wawancara tertulis. Kajian literatur dilakukan guna mendalami penelitian- penelitian terdahulu dan konsep manajemen rantai pasokan. Sementara proses wawancara terbuka secara tertulis dilakukan guna efektivitas komunikasi dengan narasumber terkait tren dan tantangan penelitian manajemen rantai pasokan. Instrumen wawancara penelitian disusun secara terbuka guna mendapatkan masukan, arahan, dan pemikiran secara terbuka dan bebas dari narasumber. Ada empat pertanyaan terbuka yang diajukan, yaitu, pertama, bagaimana perkembangan penelitian bidang manajemen rantai pasokan selama lima tahun terakhir; kedua, bagaimana tren dan tantangan penelitian bidang manajemen rantai pasokan baik di kalangan akademisi, pelaku usaha, maupun sektor publik; ketiga, apa dan bagaimana urgensi penelitian bidang manajemen rantai pasok di Indonesia, baik di lingkungan akademik, bisnis dan industri, sektor privat, serta sektor publik; keempat, spesifikasi topik manajemen rantai pasok yang ditekuni oleh narasumber.

\section{ANALISIS DAN BAHASAN TEMUAN \\ Isu Penelitian Manajemen Rantai Pasok (Perkembangan, Tren dan Tantangan, serta Kemendesakan)}

Isu penelitian manajemen rantai pasok diolah dari berbagai narasumber yang berdomisili di institusi perguruan tinggi kota Bandung, seperti Universitas Kristen Maranatha, Universitas Katolik Parahyangan, Institut Teknologi Bandung, dan Institut Teknologi Harapan Bangsa. Dosen-dosen yang mendalami kajian manajemen rantai pasokan di institusi-institusi tersebut dianggap sebagai ahli di bidang SCM. Narasumber memberikan opini mengenai tren, perkembangan, tantangan, serta kemendesakan bidang manajemen rantai pasokan melalui wawancara tertulis. Peneliti mengkaji artikel jurnal dan laporan penelitian yang pernah dilakukan oleh dosen-dosen tersebut. Dari hasil kajian tersebut, peneliti melakukan kategorisasi mengenai isu, objek, dan metodologi penelitian yang banyak dilakukan oleh para ahli SCM tersebut.

Menurut Rainisa Maini Heryanto, S.T., M.T. dari Fakultas Teknik Universitas Kristen Maranatha (Heryanto, 2017) mengatakan bahwa perkembangan penelitian bidang manajemen rantai pasok dalam lima tahun terakhir berkembang sangat pesat khususnya di Indonesia. Hal tersebut ditandai dengan semakin banyaknya topik-topik dan metode-metode baru yang muncul terkait dengan manajemen rantai pasok. Semakin dikenalnya bidang manajemen 
rantai pasok di dalam dunia bisnis dan industri membuat semakin banyak kajian-kajian yang membahas tentang bidang tersebut dan membuat para pakar dan peneliti akhirnya memutuskan untuk membuat suatu organisasi yang bernama Institut Supply Chain dan Logistik Indonesia (ISLI) sekitar bulan Oktober 2016. Fungsi dari ISLI adalah sebagai wadah untuk para pakar dan peneliti (baik dosen maupun mahasiswa) untuk saling berbagi pengetahuan khususnya dalam bidang logistik dan manajemen rantai pasok.

Sementara menurut Rainisa Maini Heryanto, S.T., M.T., tren dan tantangan penelitian dalam bidang SCM juga semakin terasa mengingat semakin banyaknya industri yang mulai mempertimbangkan aspek manajemen rantai pasok dalam menjalankan bisnisnya. Banyaknya permasalahan yang muncul dalam dunia industri dan sektor publik yang semakin lama semakin kompleks membuat penelitian manajemen rantai pasok akan semakin diminati dan dijadikan tantangan tersendiri bagi para peneliti untuk dapat menemukan solusi terhadap permasalahan yang dihadapi. Selain itu, penelitian manajemen rantai pasok tidak hanya terkait dengan produk barang atau jasa yang nyata, beberapa penelitian yang ada bahkan telah menghubungkan antara manajemen rantai pasok dengan berbagai bidang kajian lainnya (penelitian multi disiplin) (Heryanto, 2017).

Dan mengenai kemendesakan penelitian SCM, Rainisa Maini Heryanto, S.T., M.T. mengatakan bahwa urgensi penelitian SCM akan semakin terasa mengingat pemahaman pelaku usaha dan sektor publik terhadap pentingnya pengelolaan rantai pasokan yang pada akhirnya memaksa perusahaan untuk memiliki departemen khusus yang menangani bidang SCM. Walaupun mungkin namanya bukan manajemen rantai pasok, namun jika dikaji lebih dalam deskripsi pekerjaan yang dijalankan berhubungan dengan aktivitas manajemen rantai pasokan. Hal ini yang akan membuat penelitian bidang manajemen rantai pasok akan semakin penting dan bermanfaat untuk mengatasi permasalahan yang ada di perusahaan (Heryanto, 2017).

Sementara menurut Dr. Lina Anatan dari Fakultas Ekonomi Universitas Kristen Maranatha mengatakan bahwa pendekatan tradisional dalam manajemen rantai pasok dinilai tidak lagi efektif dalam perekonomian global saat ini, sehingga lahir konsep baru yang memfokuskan pada keterkaitan antara manajemen kualitas dan manajemen rantai pasok yang dikenal dengan konsep SCQM (Supply Chain Quality 152
Management). Pendekatan ini memfokuskan pada upaya mengevaluasi isu-isu manajemen kualitas dalam konteks rantai pasok (Anatan, 2017).

Melihat tren dan tantangan permasalahan manajemen rantai pasokan, Dr. Lina Anatan mengatakan bahwa karakteristik mendasar dalam persaingan bisnis saat ini adalah kompetisi antar jaringan (network), dimana persaingan terjadi tidak lagi antar perusahaan/organisasi secara individu, melainkan antar rantai pasok. Kondisi ini membawa dampak pada adanya tuntutan bagi perusahaan untuk memiliki produk pada waktu dan tempat yang tepat. Akan tetapi, seringkali perusahaan dihadapkan pada tantangan/hambatan ketidaktersediaan sumber daya atau kompetensi, sehingga diperlukan kerja sama dengan perusahaan lain untuk mendapatkan sumber daya atau kompetensi tersebut. Dalam kondisi, isu-isu tentang kualitas dan sharing informasi, serta praktik-praktik dalam rantai pasok perlu mendapat perhatian penting bagi peneliti baik di sektor akademik, industri, maupun publik, sehingga dapat memberikan solusi praktis dalam upaya mengurangi ketidakpastian akibat lingkugan persaingan yang sangat dinamis, formulasi strategi pengembangan produk baru, memperbaiki penjadwalan, dan hal-hal lain untuk meningkatkan keunggulan kompetitif dan kinerja baik perusahaan maupun rantai pasok (Anatan, 2017).

Dan disampaikan oleh Dr. Lina Anatan mengenai kemendesakan pemanfaatan manajemen rantai pasok terutama Indonesia sebagai negara kepulauan, Indonesia memiliki tantangan tersendiri dalam pengelolaan rantai pasok, khususnya terkait logistik. Penelitian dalam bidang manajemen rantai pasok di berbagai lingkungan tersebut perlu memfokuskan pada isu bagaimana mengembangkan desain logistik yang terintegrasi terkait jaringan fasilitas, jaringan transportasi, dan teknologi yang terintegrasi. Beberapa topik SCM yang perlu diangkat dalam penelitian adalah mengenai hambatan dan fasilitator dalam kolaborasi dan integrasi rantai pasok, serta peran praktik-praktik supply chain quality management (SCQM) dalam meningkatkan kinerja organisasional (Anatan, 2017).

Narasumber dari Universitas Katolik Parahyangan Maranatha, Dr. Gandhi Pawitan dan Dr. Maria Widyarini memiliki kesamaan bidang kajian pada industri usaha mikro, kecil, dan menengah. Dr. Maria Widyarini menyoroti bahwa masih diperlukan dukungan literature 
yang dapat dijadikan rujukan perkembangan isu rantai pasok di Indonesia. Sebagai negara yang sedang mengalami perkembangan pembangunan infrastruktur, Indonesia akan memunculkan banyak kesempatan bagi para akademisi untuk melakukan kajian ilmiah. Selain itu, perkembangan ekonomi global dan kehadiran Masyarakat Ekonomi Asean (MEA) memunculkan tantangan tersendiri bagi para akademisi dan industri untuk semakin memperkuat rantai pasok di Indonesia. Kolaborasi antara akademisi dan industri akan mendukung perbaikan manajemen rantai pasok di Indonesia yang semakin baik (Widyarini, 2017).

Sementara menurut Dr. Gandhi Pawitan, rantai pasok akan menjadi salah satu kunci keberhasilan dalam bisnis saat ini, terutama yang berbasiskan pada digital platform. Rantai pasok tidak hanya dilihat dari saluran distribusinya saja, tapi juga berkaitan dengan aspek perilaku dari aktor yang terlibat. Pada era gloabalisasi saat ini, pelaku rantai pasok banyak didominasi oleh pelaku dengan skala medium dan kecil, tapi dengan jangkauan yang luas dan kadang tidak berbatas geografis. Seperti misalnya, keberhasilan dari Alibaba adalah adanya kompetensi Alibaba dalam menangkap dan mengelola pelaku pemasok kecil dan menengah. Namun Beliau mengingatkan tantangan yang perlu diantisipasi adalah koordinasi dan networking, serta komunikasi antar aktor yang terlibat sehingga aspek penelitian dalam bidang rantai pasok akan menjadi sangat luas, baik mencakup aspek sosial, politik, budaya, ekonomi, keamanan, serta teknologi. Selain itu, tantangan inovasi menjadi kunci pokok keberhasilan dalam manajemen rantai pasok (Pawitan, 2017).

Institut Teknologi Harapan Bangsa (ITHB) memberikan perhatian khusus pada bidang SCM dengan membentuk program studi khusus supply chain management. Fokus program studi ini berkaitan dengan pengelolaan semua aktivitas yang terlibat dalam mengantarkan produk dari bahan baku sampai ke pelanggan. Seluruh topik perkuliahan diarahkan pada integrasi jaringan rantai pasokan. Selain itu, ITHB mempunyai pusat studi yang dinamakan Center for Supply Chain Information System (COSIS). Visi dari pusat studi ini adalah memberikan solusi dalam penerapan manajemen rantai pasokan kepada usaha kecil dan menengah dengan menggunakan sistem informasi SCM. Kegiatan yang dilakukan pusat studi ini adalah penelitian tentang aplikasi dan kebutuhan SCM, mengembangkan sistem informasi SCM, dan memberikan solusi implementasi SCM kepada pelaku usaha kecil dan menengah ${ }^{2}$. Program studi dan pusat penelitian SCM memperlihatkan bahwa kebutuhan keahlian manajemen rantai pasok sangat diperlukan guna mendukung kemajuan usaha yang akan mendorong peningkatan perekonomian Indonesia.

\section{Desain Metodologi Penelitian Manajemen Rantai Pasok}

Kotzab dan Seuring (2005) dalam buku Research Metodologies in Suppy Chain Management mengemukakan ada lima metodologi yang dapat digunakan pada penelitian manajemen rantai pasok, yaitu justifikasi substansi untuk membangun teori, metode survey, studi kasus, metode action research, dan metode modelling pada manajemen rantai pasok. Berbagai penelitian yang disajikan dalam buku tersebut memperlihatkan bahwa tidak ada metodologi penelitian manajemen rantai pasokan yang benar atau salah. Setiap metodologi mempunyai kelebihan dan kekurangan tersendiri. Hal ini menunjukkan bahwa luasnya pemikiran teknis di lapangan tidak dapat dibatasi oleh metodologi penelitian. Pada penelitian ini, peneliti mendapati empat metode yang digunakan oleh para ahli dalam menjalankan penelitian SCM, yaitu:

\section{Substantive justification for theory building}

Justifikasi substansi bertujuan untuk membangun teori menurut tinjauan literature terdahulu. Pada penelitian ini, peneliti menemukan contoh penelitian yang menggunakan justifikasi substansi pada penelitian yang dilakukan Simatupang (2007) yang berjudul A Taxonomy of Supply Chain Collaboration. Penelitian dilakukan dengan meneliti kembali literature terdahulu kemudian mengembangkan penelitian taksonomi pada kolaborasi rantai pasok. Masalah yang ditemukan pada penelitian ini adalah kurangnya perhatian yang diberikan untuk menyediakan keterkaitan antara berbagai bidang penelitian kolaborasi rantai pasokan yang diterbitkan dalam literature. Untuk mengatasi masalah tersebut, Simatupang membangun sebuah taksonomi dengan tujuan mengidentifikasi dan menghubungkan area penelitian rantai pasok (Simatupang, 2007).

\footnotetext{
${ }^{2}$ www.ithb.ac.id, diakses 30 Juni 2017.
} 


\section{Surveys in supply chain management}

Metode survey merupakan metode penelitian yang umum digunakan oleh semua jenis penelitian. Metode ini dapat digunakan pada penelitian-penelitian manajemen rantai pasokan. Anatan (2012) dalam penelitian "Peran Implementasi Manajemen Rantai Pasokan dalam Perekonomian Era Global (Studi pada Perusahaan Manufaktur di Indonesia)" menggunakan metode survey melalui pengiriman surat pos. Teknik survey berusaha mendapatkan data dari tiga variabel SCM melalui kuesioner. Tingkat pengembalian kuesioner hanya $16,8 \%$ dan jumlah kuesioner yang valid untuk diolah hanya $14,6 \%$. Kelemahan metode survey pada penelitian SCM adalah informasi dasar mengenai metode survey yang digunakan kurang jelas, misal jenis kuesioner yang digunakan, ukuran sampel tidak dicantumkan, dan persentase kuesioner yang valid untuk diproses relative kecil jika pengambilan data tidak didampingi oleh tim peneliti.

\section{Case study research in supply chains}

Menurut Basuki (2010), studi kasus adalah suatu bentuk penelitian tentang suatu masalah yang memiliki kekhususan dan dapat dilakukan dengan pendekatan kualitatif maupun kuantitatif, dengan sasaran perorangan, kelompok, bahkan masyarakat luas. Penekanan studi kasus adalah memaksimalkan pemahaman tentang kasus yang dipelajari dan bukan untuk menggeneralisasi kasus pada kasus lain. Penelitian manajemen rantai pasok banyak yang menggunakan metode studi kasus. Tujuan penelitian studi kasus SCM adalah menganalisa kondisi manajemen rantai pasokan ketika dilakukan penelitian dan mencoba memberikan solusi pada permasalahan kasus rantai pasokan yang terjadi di perusahaan tertentu. Selain itu, penelitian studi kasus dapat digunakan untuk melihat isu tertentu pada objek penelitian, baik industri atau perusahaan yang lingkupnya lebih sempit.

Contoh telaah jurnal penelitian terkait penelitian SCM yang menggunakan metode studi kasus berjudul A New Collaborative Approach for Horticultural Supply Chain oleh Simatupang (2013). Penelitian ini mempelajari kasus apakah kurangnya rantai nilai menjadi penyebab logistik pertanian menjadi tidak efisien, hilang, dan terbelakang.
Diagnosis dilakukan pada perusahaan bibit Alamanda Sejati Utama yang telah menerapkan kolaborasi untuk rantai pasokan hortikultura dalam sistem bisnisnya. Dan dari studi kasus ini dapat disimpulkan bahwa untuk menjamin kualitas dan stabilitas pasokan produk hortikultura, perhatian harus diberikan tidak hanya kepada operasi yang dijalankan perusahaan, tetapi juga untuk operasi yang dilakukan oleh petani sebagai produsen utama produk pertanian (Simatupang, 2013).

\section{Action research in supply chains}

Action research dikenal dengan banyak nama, seperti participatory action research, collaborative inquiry, emansipatory research, dan contextural action research (Hasan, 2009). Action research bertujuan untuk memberikan kontribusi pada tataran praktis terhadap masalah yang dihadapi pada objek penelitian. Metode penelitian ini dilakukan secara sistematis dan memastikan intervensi yang dilakukan atas dasar pertimbangan teoritis. Penelitian SCM yang menggunakan metode action research akan mengarahkan objek penelitian pada tataran solusi dari permasalahan yang dialami terkait rantai pasokannya. Dalam penelitian "Supply Chain Collaboration for Ensuring Retail Product Availability at Glaxosmithkline", Muslimah melihat GlaxoSmithKline sebagai salah satu perusahaan multinasional terbesar menghadapi ketidakpastian permintaan. Akar penyebab memperlihatkan adanya outlet ritel yang memiliki stok minimal, menyesuaikan pesanan pembelian tanpa berbagi informasi, beberapa pembayaran yang tidak dibayar tepat pada waktunya, dan adanya kesalahan manusia atau kecurangan internal. Sebagai penelitian action research, peneliti memberikan solusi dengan mengukur stok eceran Glaxosmithkline, menyesuaikan tingkat stok minimum di gerai ritel, melakukan update rutin dengan menggunakan sistem sharing information, memaksa pembayaran tepat waktu, dan melakukan control internal pada tingkat manajerial untuk meminimumkan human error (Muslimah \& Simatupang, 2014).

\section{Konsentrasi Objek Penelitian Manajemen Rantai Pasok}

Dari hasil telaah berbagai jurnal dan laporan penelitian ahli SCM yang berada di beberapa 
institusi perguruan tinggi kota Bandung, peneliti melihat setiap industri yang bergerak di Indonesia mempunyai kemendesakan untuk dikaji guna memperbaiki sistem manajemen rantai pasokan di berbagai industri. Fokus pada industri vital di Indonesia akan membantu pemerintah memeratakan pembangunan ekonomi, menjaga stabilitas dan ketahanan kebutuhan pokok masyarakat, serta mencapai tingkat kesejahteraan masyarakat yang lebih baik. Industri-industri vital yang perlu dijadikan konsentrasi objek penelitian dalam kajian bidang manajemen rantai pasok adalah sebagai berikut:

\section{Industri Peternakan}

Penelitian yang dilakukan oleh Gandhi Pawitan (2014) mengenai evaluasi implementasi KUPS pada tingkat peternak di Jawa Barat dilatarbelakangi oleh ketidakseimbangan antara supply dan demand pasokan daging sapi yang menyebabkan harga daging sapi mengalami tekanan cukup tinggi di Jawa Barat. Peningkatan hasil produksi sapi potong dan sapi perah tidak sebanding dengan peningkatan jumlah penduduk walaupun kontribusi Jawa Barat sebagai salah satu sentra penghasil sapi potong dan perah relatif mengalami peningkatan setiap tahunnya. Permasalahan yang terjadi ditemukan pada kurangnya pemanfaatan KUPS yang disediakan oleh pemerintah karena keterbatasan informasi detail mengenai skim kredit UMKM tersebut. Lemahnya industri peternakan di Indonesia karena kebijakan-kebijakan yang kurang tepat sasaran menjadi salah satu penyebab ketidakstabilan harga pada musim-musim tertentu. Bagi peneliti khususnya bidang kajian manajemen rantai pasokan, industri peternakan menjadi konsentrasi objek penelitian untuk didalami guna membantu terjadinya keselarasan antara permintaan dan penawaran masyarakat sehingga kestabilan harga dapat terjamin.

\section{Industri Pertanian (perberasan)}

Widyarini (2016) dalam artikel berjudul Social Interaction and Price Transmision in Multi-Tier Food Supply Chain menyajikan penelitian kualitatif dengan tujuan memeriksa jaringan pasokan beras yang sudah mapan di kabupaten Karawang. Bukti menunjukkan bahwa hubungan sosial sangat berperan dalam transmisi informasi harga antar pelaku jaringan untuk mempertahankan aliran beras, mengurangi risiko, dan menghindari kerugian akibat buruknya kualitas beras. Ditegaskan oleh Widyarini (2014), dalam penelitian sebelumnya mengenai transmisi harga, bahwa studi tentang transmisi harga menjadi isu penting ketika melibatkan kebutuhan pokok masyarakat dalam suatu negara.

Dewi (2010) dalam penelitian analisis kinerja manajemen rantai pasokan beras di perusahaan umum badan urusan logistik divisi regional Jawa Barat menggambarkan rantai pasokan beras Perusahaan Umum Bulog dari lokasi yang mengalami kelebihan pasokan produksi ke lokasi yang kekurangan pasokan konsumsi di Jawa Barat dan sekitarnya. Dari hasil penelitian tersebut, menunjukkan jaringan transportasi yang dapat dibentuk secara optimal dengan memaksimumkan penerimaan beras berdasarkan kapasitas penyimpanan dan pendistribusian dari satu lokasi ke lokasi lainnya. Dan penelitian ini memberikan saran agar Bulog dapat mengimplementasikan bebrapa implikasi manajerial untuk memperbaiki kinerja dengan tetap kompetensi bidang logistik dengan dipadukan perbaikan teknologi serta peningkatan kualias sumber daya manusia.

Yun dan Kurniawan (2014) dalam penelitian mengenai kaitan supply chain dengan ketahanan pangan di pedesaan, mengatakan bahwa tantangan pembangunan pertanian tidak hanya bertumpu pada peningkatan produktivitas dan inovasi di sektor usaha tani tetapi juga produktivitas dan inovasi sektor lain terkait usaha tani, seperti pengolahan, pengemasan, dan jasa logistik. Pengelolaan dan pengukuran manajemen resiko pun diperlukan sebagai pendekatan dalam mengoptimalkan jaringan rantai pasokan. Keberhasilan logistik produk pertanian ditentukan oleh seluruh aktivitasaktivitas dalam pengelolaan rantai pasok tersebut, bukan hanya kegiatan pendistribusian saja.

Menurut Mahbubi (2013), Indonesia merupakan konsumen beras terbesar di dunia dengan konsumsi $114 \mathrm{~kg} / \mathrm{kapita} / \mathrm{tahun}$, sedangkan rata-rata di Cina adalah 90 $\mathrm{kg} / \mathrm{kapita} /$ tahun, Malaysia sebesar 74 $\mathrm{kg} / \mathrm{kapita} / \mathrm{tahun}$, dan Thailand sebanyak 70 $\mathrm{kg} / \mathrm{kapita} /$ tahun. Tingginya konsumsi beras di Indonesia akan menjadi pemicu terjadinya krisis berantai, seperti krisis 
nutrisi, kesehatan, ekonomi, sosial, dan politik. Industri perberasan di Indonesia menjadi salah satu industri vital yang memegang peranan ketahanan pangan karena masih menjadi kebutuhan pokok masyarakat Indonesia. Menurut Behzadi (2017), rantai pasokan agribisnis melibatkan lebih banyak sumber ketidakpastian dibandingkan rantai pasokan manufaktur sehingga membutuhkan penanganan khusus baik dalam pengelolaan teknis maupun riset. Aplikasi hasil penelitian-penelitian terkait sektor pertanian dan perberasan di Indonesia, khususnya di Jawa Barat dapat meningkatkan kuantitas dan kualitas proses produksi padi, membangun jaringan distribusi beras, dan menjaga disparitas harga beras dari mata rantai petani sampai dengan konsumen akhir. Fokus objek penelitian manajemen rantai pasokan di industri pertanian terutama perberasan dapat menjadi pilihan peneliti yang ingin terus mendalami kajian supply chain pertanian.

\section{Industri Perkebunan (agribisnis dan hortikultura)}

Fuqron (2014) dalam penelitian berjudul Analisis Manajemen dan Kinerja Rantai Pasokan Agribisnis Buah Stroberi di Kabupaten Bandung menunjukkan bahwa produksi buah lokal merupakan peluang dalam rangka memenuhi permintaan pasar dalam negeri yang masih didominasi oleh buah impor. Dengan mengamati objek penelitian kawasan sentra stroberi di Kabupaten Bandung, Fuqron (2014) memetakan rantai pasokan beserta manajemennya untuk mengidentifikasi faktor penghambat dan pendorong rantai pasok agribisnis stroberi serta menganalisis kinerja rantai pasok agribisnis stroberi. Dan hasil penelitian mengemukakan bahwa rantai pasokan stroberi belum efisien, terlihat dari biaya operasional yang sangat besar serta setiap mata rantai menarik keuntungan yang besar pula. Togar (2013) meneliti apakah kurangnya rantai nilai adalah penyebab logistik pertanian yang tidak efisien, hilang, dan terbelakang. Penelitian berjudul "A New Collaborative Approach for Horticultural Supply Chain" ini mengidentifikasi masalah dan akar penyebab logistik pertanian serta perkebunan dan sayuran dengan model rantai pasokan kolaborasi. Penelitian ini bermanfaat bagi industri hasil pertanian agribisnis dan pelaku usaha yang tertarik mengembangkan model rantai pasokan hortikultura kolaboratif lebih lanjut. Hasil penelitian terhadap objek penelitian industri agribisnis dan hortukultura dapat meningkatkan kinerja manajemen rantai pasokannya, maka dari itu konsentrasi objek penelitian yang perlu digarap terkait kajian SCM salah satunya adalah industri perkebunan.

\section{Industri Manufaktur}

Anatan (2012) melakukan penelitian pada perusahaan manufaktur yang ada di Indonesia. Tujuan penelitian tersebut adalah ingin mengetahui hubungan antara praktik manajemen rantai pasok dengan kinerja mata rantainya dengan dimoderasi oleh variabel ketidakpastian lingkungan pada rantai pasok. Hasil penelitian menunjukkan bahwa aktivitas manajemen rantai pasokan mempengaruhi kinerja rantai pasoknya, serta peran faktor ketidakpastian lingkungan berperan dalam memoderasi hubungan praktik SCM dengan kinerjanya. Dengan pemahaman faktor-faktor yang mempengaruhi kinerja rantai pasok, perusahan diharapkan dapat mempersiapkan bagaimana teknis dan praktis praktik manajemen rantai pasokannya. Diharapkan penelitian yang fokus pada industri manufaktur ini memberikan kontribusi dalam meningkatkan daya saing perusahaan dari sisi pengelolaan manajemen rantai pasok sehingga berdaya saing dan berkinerja baik.

Ditegaskan oleh Anatan (2014) bahwa perusahaan manufaktur disarankan untuk menerapkan praktik pengelolaan rantai pasokan dan merumuskan strategi yang tepat agar dapat bersaing secara efektif dalam lingkungan bisnis yang semakin bergejolak dan tidak dapat diprediksi. Ahli SCM perlu terus memberikan masukan bagi industri manufaktur agar sustanaibilitas perusahaan dapat dijamin. Maka dari itu, fokus terhadap industri manufaktur sebagai objek penelitian kajian manajemen rantai pasokan menjadi penting untuk didalami. Selain itu, kemitraan antara akademisi dengan praktisi manufaktur sebagai dasar pertimbangan pengambilan keputusan dan perumusan kebijakan strategi manufaktur yang tepat. 


\section{Industri Farmasi}

Muslimah (2014) melakukan penelitian pada industri farmasi dengan objek penelitian perusahaan multinasional farmasi besar GlaxoSmithKline. Perusahaan farmasi ini sedang menghadapi peningkatan ketidakpastian permintaan produk. Dengan mengidentifikasi akar penyebab terjadinya ketidakpastian permintaan produk GlaxoSmithKline, penelitian ini memberikan rekomendasi agar perusahaan melakukan perhitungan ulang terkait stok minimum (safety stock) pada gerai ritel obat dengan sumber informasi dari mata rantai lainnya. Sherlywati (2017) pada analisis perbandingan komoditas kontrasepsi pada jalur swasta dan jalur pemerintah memaparkan bagaimana rantai pasokan yang lebih efektif dalam mendistribusikan alat dan obat kontrasepsi yang tepat jenis, tepat jumlah, tepat waktu, dan tepat sasaran pada pasangan usia subur. Penelitianpenelitian manajemen rantai pasokan di industri farmasi perlu difokuskan agar ketersediaan obat dapat dijamin sampai ke pelosok nusantara. Maka dari itu, objek penelitian industri farmasi menjadi tantangan tersendiri bagi akademisi dalam menjalankan penelitian kajian manajemen rantai pasokan.

\section{Industri Kontruksi dan Alat Berat}

Sektor konstruksi, khususnya alat berat jarang diperbincangkan dalam dunia penelitian. Simatupang (2013) dalam buku "Logistics and Supply Chain in Indonesia: Emerging Practices", menyampaikan sebuah penelitian dengan konsentrasi objek penelitian di sektor konstruksi-alat berat. Dilatarbelakangi oleh peluang bisnis alat berat yang menjadi sasaran produsen di Indonesia, Simatupang (2013) mengatakan bahwa peralatan berat memegang peranan penting dalam menyelesaikan proyek dan fungsi produksi namun mobilisasi dan pemanfaatan alat berat merupakan tugas yang rumit. Penelitian ini dilakukan untuk mengkarakterisasi rantai pasokan alat berat di negara berkembang dan mengidentifikasi hambatan serta peluang industri alat berat. Hasil penelitian menunjukkan bahwa rantai pasokan alat berat menentukan keberhasilan pembangunan infrastruktur. Penelitian ini merupakan langkah awal menuju penjabaran rantai pasokan alat berat di Indonesia.

Konsentrasi objek penelitian di sektor konstruksi pada penelitian selanjutnya sangat dibutuhkan. Proyeksi masa depan menunjukkan bahwa akan ada peningkatan pembangunan infrastruktur untuk mempercepat dan memperluas pembangunan ekonomi dan sosial. Hal ini menjadi tanda bahwa rantai pasokan konstruksi yang efektif dan efisien akan menjadi kunci pembangunan infrastruktur. Oleh karena itu, fokus objek penelitian sektor konstruksi pada kajian manajemen rantai pasokan menjadi penting untuk diperdalam.

\section{Sektor publik}

Peneliti menelaah penelitian berbasis sektor publik terkait manajemen rantai pasok yang dilakukan oleh Oktarina, dkk (2011) bertemakan "Peta Penelitian Logistik Tanggap Darurat Bencana dan Peluang Penelitiannya di Indonesia". Dikatakan bahwa beberapa tahun terakhir penelitian manajemen rantai pasok dalam rangka menanggulangi bencana menjadi perhatian kalangan peneliti. Penelitian ini mencoba memetakan dan mengidentifikasi arah penelitian yang berpotensi di bidang logistik penanggulangan bencana, isu yang hangat dibicarakan, dan memberikan titik awal bagi peneliti yang tertarik menjalankan penelitian bidang SCM. Walau hanya menyajikan kajian literatur, Oktarina dkk (2011) menunjukkan tren penelitian logistik penanggulangan bencana dan gambaran permasalahan aktual serta peluang penelitian dimasa yang akan datang.

Rantai pasokan pada bidang manajemen publik yang banyak disoroti dalam pembangunan nasional adalah pengadaan barang dan jasa di lingkungan pemerintah. Hafidz (2014) menyoroti kinerja pemerintah dalam pengadaan barang dan jasa pemerintah dari segi reformasi hukum birokrasi. Pengadaan barang dan jasa tidak terlepas dari proses manajemen rantai pasok yang dilengkapi dengan perangkat peraturan dalam koridor hukum yang berlaku. Pengadaan barang dan jasa yang dilakukan pemerintah merupakan bentuk suksesi pembangunan nasional jika dikelola dengan tepat guna, tepat langkah, serta patuh pada peraturan perundang-undangan. 
Konsentrasi pada objek penelitian sektor publik bukan hanya di bidang logistik penanggulangan bencana, tetapi kinerja dan prosedur yang dijalankan oleh pemerintahan, badan layanan umum negara, sampai pasokan pengadaan barang/jasa di instansi pemerintahan membutuhkan penelitian agar kinerja dan prosedur yang dijalankan dapat meningkatkan kepuasan dan kepercayaan masyarakat terhadap pemerintah. Hal ini menjadi tantangan sekaligus panggilan bagi kalangan peneliti untuk melakukan penelitian kajian SCM pada objek penelitian sektor publik, sekaligus memberikan kontribusi pemikiran bagi pembangunan bangsa melalui penelitian objek-objek sektor publik.

\section{Sektor Pertambangan}

Gunawan, Primiana, Rufaidah, dan Hidayat (2015) memprediksi produksi tambang batu bara akan meningkat bukan hanya untuk memenuhi kebutuhan dalam negeri tetapi juga untuk memenuhi permintaan ekspor. Kondisi sumber daya batu bara Indonesia masih melimpah, namun harga bahan bakar minyak yang tetap tinggi menuntut industri beralih menggunakan batu bara. Dengan demikian permintaan batu bara baik dari dalam negeri maupun negara importir menuntut kenaikan produksi batu bara. Melihat fenomena tersebut, Gunawan, dkk (2015) melihat pengaruh rantai pasokan dan orientasi strategis melalui strategi kompetitif dan dampaknya terhadap kinerja bisnis batubara. Hasil penelitian menunjukkan kemampuan praktisi industri pertambangan batu bara di Indonesia dalam menjalankan manajemen rantai pasokan, strategis orientasi, dan strategi bersaing berada dalam kategori baik; terlihat adanya hubungan antara supply chain dengan orientasi strategis dimana hal ini menunjukkan perubahan supply chain sejalan dengan perubahan orientasi strategis; kontribusi orientasi strategis berpengaruh paling dominan jika dibandingkan dengan rantai pasokan terhadap strategi persaingan dan kinerja perusahaan tambang batu bara di Indonesia. Penemuan lainnya adalah rantai pasokan memberikan pengaruh positif terhadap strategi bersaing rantai pasokan dan performa bisnis, orientasi strategis akan memberikan pengaruh positif terhadap strategi bersaing. Dari pandangan penelitian sektor pertambangan Gunawan, Primiana, Rufaidah, dan Hidayat (2015), peneliti SCM diberikan ruang untuk turut serta mendedikasikan pemikirannya dalam rangka meningkatkan rantai pasokan kinerja bisnis sektor pertambangan karena praktik supply chain yang baik mendukung peningkatan kinerja perusahaan pertambangan.

\section{KESIMPULAN DAN SARAN \\ Kesimpulan}

Menurut para ahli SCM yang terlibat dalam penelitian ini, perbincangan isu penelitian manajemen rantai pasok menjadi hangat dibicarakan mengingat prioritas pembangunan ekonomi nasional dimulai dari perbaikan infrastruktur logistik dan infrastruktur rantai pasokan. Perkembangan, tren dan tantangan, serta kemendesakan penelitian SCM perlu disadari baik oleh kaum akademisi, praktisi, dan pemerintah agar arah penelitian dapat difokuskan untuk membangun kebutuhan infrastruktur di berbagai industri dan sektor publik. Simpulan mengenai isu penelitian manajemen rantai pasok menurut pada ahli pada penelitian ini adalah sebagai berikut:

1.Perkembangan penelitian manajemen rantai pasok ditandai oleh semakin banyaknya topik dan metode baru yang muncul terkait SCM baik dalam dunia bisnis, industri, maupun lembaga pemerintahan. Pendekatan tradisional dalam manajemen rantai pasok dinilai tidak lagi efektif dalam perekonomian global saat ini, sehingga lahir banyak konsep baru yang memfokuskan keterkaitan manajemen rantai pasok dengan kajian manajemen lainnya, seperti misalnya supply chain quality management, supply chain risk management, supply chain berbasis platform digital, dan supply chain sustainability management.

2.Tren dan tantangan penelitian manajemen rantai pasokan semakin terasa dengan banyaknya permasalahan yang muncul dalam dunia industri dan sektor publik yang semakin lama semakin kompleks. Maka dari itu, penelitian SCM mulai dilakukan dengan menggandeng ilmu kajian lainnya sehingga menjadi penelitian multidisplin. Tren dan tantangan lain bidang SCM adalah kompetisi antar jaringan (network) dimana persaingan bukan lagi terjadi antar perusahaan secara individu melainkan antar rantai pasok. Jadi tantangan yang akan dihadapi adalah bagaimana koordinasi, 
networking, serta komunikasi antar aktor yang terlibat akan menciptakan aspek penelitian dalam bidang rantai pasok menjadi komprehensif, baik mencakup aspek sosial, politik, budaya, ekonomi, keamanan, serta teknologi.

3.Dengan meningkatnya pemahaman pelaku usaha dan sektor publik akan pentingnya pengelolaan rantai pasok, kemendesakan penelitian SCM menuntut subjek dan objek penelitian untuk melibatkan berbagai kajian SCM guna meningkatkan kinerja dan mengatasi permasalahan yang terjadi pada setiap mata rantai. Terlebih lagi sebagai negara kepulauan, Indonesia memiliki tantangan tersendiri khususnya dalam permasalahan logistik. Kemendesakan penelitian SCM perlu difokuskan pada isu bagaimana mengembangkan desain rantai pasok dan logistik yang terintegrasi dengan jaringan fasilitas, transportasi, dan teknologi.

Ada empat desain metodologi penelitian manajemen rantai pasok yang ditemukan pada telaahan kajian SCM dari para ahli SCM yang terlibat dalam penelitian ini yang dapat dijalankan dalam penelitian SCM, yaitu pertama, substantive justification for theory building, digunakan untuk membangun teori/konsep SCM tertentu berdasarkan tinjauan literature terdahulu. Kedua, surveys in supply chain management, merupakan metode penelitian yang umum digunakan dengan instrument penelitian kuesioner. Ketiga, case study research in supply chain, penekanan studi kasus adalah memaksimalkan pemahaman tentang kasus yang dipelajari dan tidak mengeneralisasi kasus pada kasus lain. Keempat, action research in supply chain, bertujuan untuk memberikan kontribusi pada tataran praktis terhadap masalah yang dihadapi objek penelitian.

Kemendesakan terhadap objek penelitian SCM dari hasil penelahaan, peneliti mendapati setiap industri memiliki concern tersendiri untuk dikaji guna menghasilkan sistem manajemen rantai pasokan. Konsentrasi objek penelitian manajemen rantai pasok yang dilakukan oleh para ahli SCM yang dilibatkan dalam penelitian ini adalah 1) industry peternakan, 2) industri pertanian dan perberasan, 3) industri perkebunan, 4) industri manufaktur, 5) industri farmasi, 6) industri konstruksi dan alat berat, dan 7) sektor publik. Seluruh konsentrasi objek penelitian SCM tersebut bersifat mendesak untuk diperdalam agar dapat meningkatkan kinerja rantai pasokan yang akan berdampak pada kemajuan sektor perekonomian Indonesia.

\section{Saran}

Dengan melihat isu penelitian kajian SCM, penelitian ini menyarankan agar peneliti yang berkecimpung di bidang SCM melakukan update dan upgrade kapasitas, informasi, serta pengetahuan mengenai perkembangan kajian manajemen rantai pasokan secara berkelanjutan. Hal ini difokuskan bagi kalangan peneliti baik di lingkungan akademisi, sektor privat, dan sektor publik. Saat ini, cakupan SCM semakin luas dan keterkaitan dengan bidang ilmu lainnya tidak bisa dielakkan. Untuk itu, sensitivitas peneliti dalam menangkap fenomena permasalahan SCM yang sedang terjadi perlu diasah dengan mengetahui bidang kajian lain yang terkait dengan kajian SCM. Bidang kajian yang tidak dapat dilepaskan dengan SCM ini akan memberikan nilai tambah dalam pengelolaan manajemen rantai pasok perusahaan. Bidang kajian tersebut misalnya seperti manajemen risiko, manajemen kualitas, manajemen sumber daya manusia, manajemen keuangan, teknologi informasi, kebijakan-kebijakan publik, dan lainnya.

Saran teknis dan praktis untuk dapat terus memantau dan mengikuti isu penelitian dan permasalahan SCM adalah dibentuknya wadah komunitas ahli SCM di kota Bandung yang bersifat independen guna berbagi informasi dan pengalaman mengenai perkembangan penelitian dan permasalahan yang sedang terjadi seputar manajemen rantai pasok. Seperti misalnya lembaga kajian Supply Chain Indonesia (SCI) di Indonesia, dan American Production and Inventory Control Society (APICS) di Amerika. Lembaga kajian SCM tersebut secara aktif melakukan berbagai riset, pelatihan, dan konsultasi bagi lembaga sektor privat maupun publik dalam hal kajian manajemen rantai pasok. Wadah komunitas SCM ini beranggotakan praktisi, akademisi, dan pemerintah di kota Bandung. Topik bahasan tidak menutup batasan isu SCM di kota Bandung saja, tetapi dapat sampai ke tingkat nasional bahkan internasional. Dan saran bagi penelitian selanjutnya adalah lakukan penelitian bidang SCM yang bersifat aplikatif serta kontributif bagi penyelesaian permasalahan manajemen rantai pasok di Indonesia. 


\section{REFERENSI}

Anatan, L., \& Ellitan, L. (2008). Supply Chain Management: Teori dan Aplikasi. Bandung. Jawa Barat: Alfabeta

Anatan, L. (2012). Peran Implementasi Manajemen Rantai Pasokan dalam Perekonomian Era Global: Studi pada Perusahaan Manufaktur di Indonesia. Zenith, 122-131

Anatan, L. (2014). Factors Influencing Supply Chain Competitive Advantage and Performance. International Journal of Business and Information, 9(3), 311-334

Anatan, L. (2017). Isu Penelitian Manajemen Rantai Pasok. (S. Sherlywati, Interviewer)

Basuki, Sulistyo. (2010). Metode Penelitian. Jakarta: Penaku

Bank, T. W. (2015). International LPI Global Ranking. Diakses pada Juni 25, 2017, dari The World Bank: lpi.worldbank.org

Behzadi, G., O'Sullivan, M.J., Olsen, T.L., Scrimgeour, F., \& Zhang, A. (2017). Robust and resilient strategies for managing supply disruptions in an agribusiness supply chain. International Journal of Production Economics, doi: 10.1016/j.ijpe.2017.06.018.

Dewi, G. C. (2010). Analisis Kinerja Manajemen Rantai Pasokan Beras: Studi Kasus di Perusahaan Umum Badan Urusan Logistik, Divisi Regional Jawa Barat 2005. Bogor: Institut Pertanian Bogor

Hafidz, J. (2014). Mengukur Kinerja Reformasi Hukum Birokrasi Pengadaan Barang dan Jasa Pemerintah. Jurnal MasalahMasalah Hukum, 43(1), 98-106

Fazli, A. Z. (2017). Luncurkan Paket Kebijakan XV, Pemerintah Fokus ke Penyedia Jasa Logistik Nasional. Diakses pada Juni 20, 2017, dari Metrotvnews: http://ekonomi.metrotvnews.com

Felicia, J. I. (2003). Dari Logistik Management menuju Supply Chain Management dan Information Technology. Bina Ekonomi , 7 (1), 34-40

Furqon, C. (2014). Analisis Manajemen dan Kinerja Rantai Pasokan Agribisnis Buah Stroberi di Kabupaten Bandung. IMAGE, 109-126.

Garside, A. K., \& Asjari, H. Y. (2015). Simulasi Ketersediaan Beras di Jawa Timur. Jurnal Ilmiah Teknik Industri, 14(1), 4758
Gunawan, G., Primiana, I., Rufaidah, P., \& Hidayat, K. (2015). The Influence of Supply Chain and Strategic Orientation Through Competitive Strategy and Its Impact on Coal Business Performance (Studies on Coal Company in Indonesia). International Journal of Scientific \& Technology Research, 4(11), 183-188

Hasan. (2009). Action Research: Desain Penelitian Integratif untuk Mengatasi Permasalahan Masyarakat. AKSES: Jurnal Ekonomi dan Bisnis , 4(8), 177188

Heryanto, R. M. (2017). Isu Penelitian Manajemen Rantai Pasokan. (S. Sherlywati, Interviewer)

Indrajit, R. E., \& Djokopranoto, R. (2002). Konsep Manajemen Supply Chain: Cara Baru Memandang Mata Rantai Penyediaan Barang. Jakarta: Grasindo

Kane, D. (2008). A Global View of Supply Chain Management. (D. Lambert, Interviewer)

Kotzab, H., Seuring, S., Muller, M., \& Reiner, G. (2005). Research Methodologies in Supply Chain Management. Germany: Springer

Kuncoro, M. (2011). Metode Kuantitatif: Teori dan Aplikasi untuk Bisnis dan Ekonomi. Yogyakarta: UPP STIM YKPN

Lambert, D. M., Cooper, M. C., \& Pagh, J. D. (1998). Supply chain management: implementation issues and research opportunities. The international journal of logistics management , 9(2), 1-20

Mahbubi, A. (2013). Model Dinamis Supply Chain Beras Berkelanjutan dalam Upaya Ketahanan Pangan Nasional. Jurnal Manajemen \& Agribisnis, 10(2), 81-89

Mentzer, E. A. (2001). Defining Supply Cahin Management. Journal of Business Logistics, 20(2), 1-25

Muslimah, M. D., \& Simatupang, T. M. (2014). Supply Chain Collaboration for Ensuring Retail Product Availability at Glaxosmithkline. 6th International Conference on Operations and Supply Chain Management, (pp. 773-784). Bali

Nicolae, L. I., Tanasescu, D., \& Popa, V. (2012). Customer Expectations Management in Store Management. Supply Chain Management Journal, 3(2), 58-75.

Oktarina, R., Bahagia, S. N., Diawati, L., \& Pribadi, K. S. (2011). Peta Penelitian Logistik Tanggap Darurat Bencana dan 
Peluang Penelitiannya di Indonesia. 6th National Industrial Engineering Conference (pp. 225-232). Surabaya: Universitas Widyatama.

Pawitan, G. (2017). Isu Penelitian Manajemen Rantai Pasok. (S. Sherlywati, Interviewer)

Pawitan, G., Widyarini, M., \& Oktavia, G. (2014). Evaluasi Implementasi KUPS pada Tingkat Peternak di Jawa Barat: Study Kasus KPSBU Lembang. Jurnal Administrasi Bisnis, 99-200.

Primiana, I. (2017). Prioritas Industri Strategis. Pemetaan Supply Chain Management Sudah Mendesak . Bandung, Jawa Barat, Indonesia: Pikiran Rakyat.

Primiana, Azis, Juanim, Yunani, \& Herwany. (2016). Improvement Strategy for Supply Chain Performance of Garment Industry to Decrease Logistics Cost and Enhace Competitiveness. Journal of Industrial and Intelligent Information, 4(2), 121-124.

Pujawan, I. N. (2005). Supply Chain Management. Surabaya: Penerbit Guna Widya.

Russel, R. S., \& Taylor, B. W. (2006). Operations Management: Quality and Competitiveness in A Global Environment. New York: WIlley and Sons Inc.

Sharma, A., Gard, D., \& Agarwal, Ashish. (2012). Quality Management in Supply Chains: The Literature Review. International Journal for Quality Research, 6(3), 193-206.

Sherlywati, S. (2017). Analisis Perbandingan Rantai Pasok Komoditas Kontrasepsi Jalur Swasta dan Jalur Pemerintah di Provinsi Jawa Barat tahun 2015. The First National Conference on Business And Entrepreneurship (pp. 75-90). Surabaya: Universitas Ciputra.

Simatupang, T. M. (2007). A Taxonomy of Supply Chain Collaboration. Jurnal Manajemen Teknologi, 6(2), 179-203.

Simatupang, T. M., Handayati, Y., \& Perdana, T. (2013). A New Collaborative Approach for Horticultural Supply Chain. In T. M. Simatupang, Logistic and Supply Chain in Indonesia: Emerging Practices (pp. 27-43). Bandung: SBM ITB.

Sridharan, R., \& Simatupang, T. M. (2013). Power and Trust in Supply Chain
Collaboration. International Journal of Value Chain Management, 7(1), 76-96

Widyarini, M., \& Simatupang, T. M. (2014). Actors Interaction on Price Transmission in Rice Supply Chain. $6^{\text {th }}$ International Conference on Operations and Supply Chain Management (pp. 304-316). Bali

Widyarini, M., Simatupang, T. M., \& Engelseth, P. (2016). Social Interaction and Price Transmission in Multi-Tier Food Supply Chains. Journal of Operations and Supply Chain Management, 110-128

Widyarini, M. (2017). Isu Penelitian Manajemen Rantai Pasok. (S. Sherlywati, Interviewer)

Widyarto, A. (2012). Peran Supply Chain Management dalam Sistem Produksi dan Operasi Perusahaan. Benefit Jurnal Manajemen dan Bisnis, 17(2), 91-98

Yun, Y. \& Kurniawan, A. (2014). Supply Chain N Logistik Dalam Kaitannya Dengan Ketahanan Pangan di Pedesaan. Prosiding Seminar Bisnis \& Teknologi, pp. 63-75. Bandar Lampung: Institut Informatika dan Bisnis Darmajaya

Peraturan Perundang-undangan:

Peraturan Pemerintah no. 26 tahun 2012 tentang Cetak Biru Pengembangan Sistem Website: Logistik Nasional Indonesia (Sislognas)

ITHB. (2015). Center for Supply Chain Information System. Diakses pada Juni 30, 2017, dari Institut Harapan Bangsa: http://ithb.ac.id 
Jurnal Manajemen Maranatha — Vol. 17 Nomor 2, Mei (2018) 